\title{
Contribution of International Development Activities to Comprehensive Internationalization of U.S. Public Universities
}

\author{
Ielyzaveta Shchepetylnykova $^{\mathrm{a}^{*}}$ and Samantha Alvis ${ }^{\mathrm{b}}$ \\ ${ }^{\mathrm{a}}$ George Washington University, Unites States, ${ }^{b}$ Texas A\&M University, Unites States \\ *Corresponding author: Email: Lissashch@gwu.edu \\ Address: George Washington University, Washington, D.C., USA
}

\section{Introduction}

In the era of globalization, increasing interdependence between countries' economic, political, and social processes creates global challenges and opportunities. Extreme variations in the international distribution of wealth have elevated developed countries as important players in tackling the world's biggest issues, such as poverty, climate change, and conflicts. However, the magnitude of the global challenges facing the planet does not allow for just a single country or organization to address them. The complex nature of the world's major issues requires significant cooperation between various actors to develop and implement solutions that stimulate economic growth (Asefa 2010).

U.S. colleges and universities have a long history of working in developing countries to bring unparalleled resources and experiences in science, technology, and teaching, which contribute to tackling global challenges. International development agencies and organizations have traditionally turned to U.S. universities and other institutions of higher education to incorporate their intellectual, research, community engagement, and capacity building expertise in efforts to address global challenges (Association of Public and Land-grant Universities 2015).

International development lacks an agreed upon definition. Frequently definitions build upon concepts of global poverty and inequality (Baker 2013; Haslam, Schafer, and Beaudet 2012; Potter 2014). For the purpose of this article, university engagement in international development has been defined, as higher education institutions' activities that are funded by a development organization (United State Agency for International Development (USAID), World Bank, NGOs, etc.), higher education institution, or local governments that work to build human, research or institutional capacity, and/or efforts to reduce poverty and inequality and improve health, education, and job opportunities. Focus on higher education institution's activities is dictated by the purpose of the research to identify international development contribution to comprehensive internationalization. Definitions of Soubbotina and Sheram (2000) and Rosenkranz (2011) informed types of activities in the developing countries that have been studied by the authors. Heyneman and Lee (2016) discussed major funders of developmental projects, including multilateral and country-based aid organizations. Nevertheless, since some institutions of higher education support their activities in developing nations with local governments' and university funding (Koehen, Deardorff, and Bolognese 2011) those projects also have been considered by the study.

Over the course of the 21 st century, international activities of colleges and universities have moved from being of marginal importance to becoming a core dimension of higher education. Interest in developing the evidence-base for best practices for internationalization of higher education has grown significantly (Deardorff, de Wit, Heyl and Adams 2012). Much of the existing literature discusses motives for internationalization, strategies applied by universities, as well as outcomes of specific institutional efforts (Altbach and Knight 2007; Deardorff et al. 2012; Edwards 2007; Hudzik 2015). Along with international development, U.S. institutions of higher education are increasingly engaging in international activities, such as study abroad, internationalization of curriculum, transnational partnership, and 
cross-border higher education provision (Deardorff et al 2012). Meanwhile, it is important to understand that these activities are not mutually exclusive, but rather complementary. This phenomenon is further elaborated in this article.

Overarching intentions of universities to holistically engage in international activities have been reflected in the concept of comprehensive internationalization defined by Hudzik (2011). Comprehensive internationalization models have been widely popularized by the American Council on Education and NAFSA: The International Educators Association. Consequently, these models have spread globally and have been applied to research and practice of international educators worldwide (Hudzik 2015).

However, a review of the literature reveals that contribution of higher education institutions' international development activities to comprehensive internationalization has lacked sufficient attention. Scholarship mainly discusses study abroad programming, internationalization at home, cross-border higher education provision by U.S. universities and transnational partnerships. Similarly, among practitioners there is a lack of recognition for the role of developmental activities in university internationalization. For example, the Senator Paul Simon Award for Campus Internationalization by NAFSA included international development, research, and public service in its criteria only seven years after the award establishment (Hudzik 2015). Universities' engagement in transnational research and sustainable development activities was also examined in an exploratory study by Koehen, Deardorff, and Bolognese (2011). Additionally, there is some research and evaluations available on outcomes of individual projects (Adesogan 2016; Collins 2012; Moss 2019) and regional initiatives (Grand Lewis, Friedman, and Schoneboom, 2010; Koehn, Demment, and Hervy 2008).

Consequently, this article contributes to the existing literature by investigating the role of international development activities in the comprehensive internationalization of U.S. institutions of higher education. Drawing on the concept of comprehensive internationalization (Hudzik 2011) and qualitative research methods, this paper addresses three questions. First, it examines contributions made by international development activities to advancing core education, research, and service missions of higher education institutions. Second, the article elaborates on intentional approach employed by U.S. public universities. Third, the authors discuss synergy between university international development activities, as well as other international programming efforts, which is essential in comprehensive internationalization of higher education institutions (American Council on Education 2017; Knight 1994; Hudzik 2011).

\section{Methodology}

The study draws on qualitative data to investigate the role of international development in comprehensive internationalization of U.S. public universities. The authors analyzed primary data collected in collaboration with the Association of Public and Land-grant Universities (APLU) on research on drivers of U.S. university engagement in international development activities. Based on the works by Hudzik $(2011,2015)$ and earlier publication by Knight (1994), this article examines three aspects of international development programming executed by U.S. public universities: intentionality of international development activities, their integration with other internationalization efforts, and contribution to advancing core learning, discovery, and engagement goals of respective U.S. public higher education institutions.

The study employed grounded theory (Glaser and Strauss 1967) in methodology design and analysis of data collected from a sample of fifteen U.S. public universities and systems. These institutions were recruited through APLU Knowledge Center for Advancing Development through Higher Education to represent the diversity of the Association's membership. In the U.S., APLU represents higher education institutions from all 50 states, including 128 public universities, 75 land-grant universities, as well as 26 university systems (Association of Public and Land-grant Universities 2018). The study originated from the association's data needs for work on advocating for U.S. university engagement in international development. 
The study employed purposive sampling (Patton 2002) to research university engagement in international development activities. Institutions considered for the sample were only those engaged in programs and activities in developing countries at the time of the study. Institutions engaged in the study were selected to represent three types of APLU members - state systems, state universities, as well as land-grant universities. An equal number of institutions located in the Northwest, Northeast, Southwest, Southeast, and Midwest areas of the U.S. were included in the sample to ensure geographical representation. The geographic regions were defined for the study by drawing upon Cooperative Extension regions defined by the APLU Board of Agricultural Assembly (BAA) (Association of Public and Land-grant Universities 2019) with an adjustment made based on research by Alvarez (1995), which identifies states bordering with Mexico as a distinct region. Thus, the Southwest and Northwest region were formed in addition to the regions defined by the BAA to achieve a more accurate measure of institutional context influence on policies and practices of international engagement.

Data collection protocols were developed based on the review of relevant theory. The authors conducted semistructured interviews with key informants on institutional engagement in international development activities (Gubrium, Holstein, Marvasti, and Karyn 2012). Four pilot interviews were conducted in late 2015 and followed by data analysis to inform the second round of interviews. Remaining interviews of the institutions in the sample were done over the course of 2016. The sample was not expended upon completion of 15 interviews due to data saturation. Figure 1 presents pseudonyms and regional affiliation of universities included in the sample.

Figure 1: Universities included in the study by pseudonyms and regional affiliation

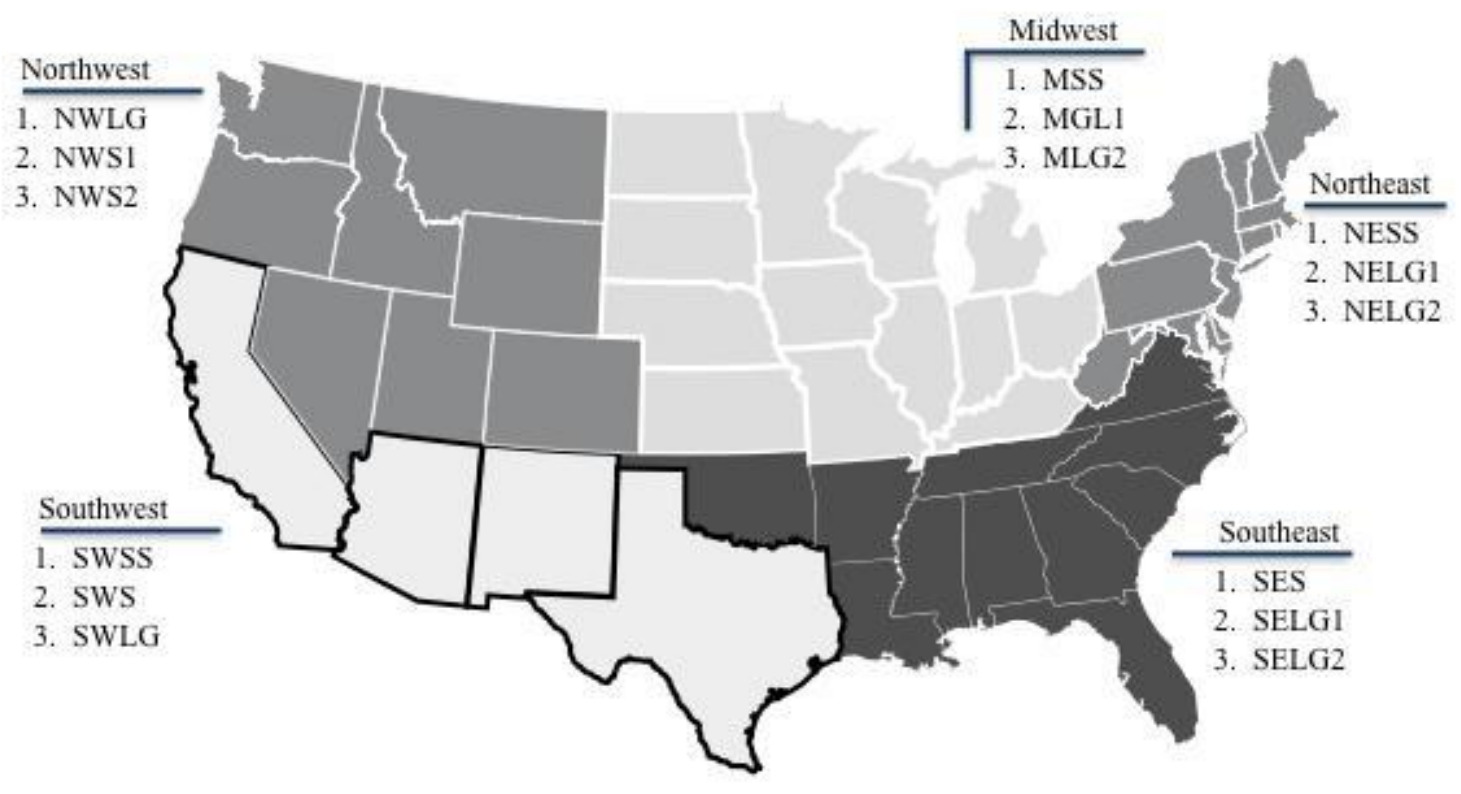

As a result of the sampling, all of the institutions included in the study are Ph.D.-conferring institutions. Based on the study methodology, institutions of different sizes were included to represent diversity of policies and practice. Three institutions in the sample enroll less than 30,000 students (20 percent) in their undergraduate and graduate programs, five institutions enroll $30-50,000$ students (33 percent), and the remaining four institutions educate over 50,000 students ( 27 percent). Each of the three university systems included in the study have student enrollment of over 150,000 . 
Key informants of the study were senior international officers and staff members (program officers or administrators) overseeing work of their respective university in developing countries. Senior international officers (SIOs) were best positioned within the institutional hierarchy to address interview questions from the perspective of the respective campuses or systems. Nevertheless, due to diversity in institutional organizational structures, SIOs of several institutions referred to other relevant university staff to participate in the study and to share relevant knowledge and experiences regarding international development activities.

Some institutions in the sample are highly decentralized in their international engagement, which does not allow for a single person or office on campus to be aware of all university activities in international development. Consequently, interviewing people from various operating units on campus that were involved in international development activities allowed for the study to grasp the full depth of institutional experiences. Decisions to interview additional staff were made in consultations with SIOs of individual institutions. As a result, thirteen institutions in the sample engaged more than one representative to inform the study. Besides SIOs, the authors interviewed some college and department chairs, who led their respective division work on international development activities.

Another source of data included in the study were institutional strategic plans, which addressed engagement in international development. These plans were analyzed to identify institution-specific characteristics, as well as commonalities in the institutional approaches to involvement in international development activities in developing countries.

The list of institutions included in the study, as well as personal identifiers of key informants, will remain confidential for the purposes of minimizing the risks of harming individual and institutional relationships with third parties, including their partner-institutions abroad, donors, and governments. All study participants gave vocal consent at the beginning of their interviews. Participants were informed of the objectives of the study, research procedures, confidentiality of personal identifiers of the interview subjects, as well as their right to withdraw from the study at any point or choose not to respond to any of the interview questions.

The data was analyzed by the constant comparative method. Memos were created during and after the interviews to identify patterns. Institutional profiles were developed, based on the interview data and strategic plans of universities in the sample (Taylo and Bogdan 1998). Content analysis of institutional profiles allowed to identify, code, classify and label common patterns and themes, which were later utilized in cross-case analysis. Some data was quantified during analysis. The data was compared across types of higher education institution (system, land-grant, state university), as well as their geographic locations (Patton 2002).

Validity of the study was ensured through a selection of a sample of institutions, which reflect the diversity of public universities in the U.S that are members of APLU. In thirteen institutional cases, the information was obtained from more than one key informant per institution. Triangulation of data through analysis of interviews, institutional strategies and reports, as well as existing scholarship was employed to determine consistency of findings among various institutions included in the sample, and sources of the data (Glesne and Peshkin, 1992).

\section{Findings}

Analysis of the study data reflects that U.S. public universities engage in international development activities to advance their teaching, research, and service missions. A statement by an international officer from MLG1 summarizes well the experiences among universities in the sample: "There are several predominant dimensions to a university's endeavors, namely education, research, and engagement. International development opportunities often touch two or all three of these dimensions simultaneously, creating an interwoven and reinforcing set of opportunities" (Interview MLG1 2016). These findings are complementary with the existing literature. Particularly, Altbach and Knight (2007) elaborate that traditional nonprofit institutions of higher education seek to internationalize for the purpose of enhancing their research and knowledge capacity, as well as increasing intercultural understanding. Hudzik (2011, 2015) 
identifies international activities contribution to advancing the university mission as an essential feature of comprehensive internationalization.

The contribution of international development activities to the mission of U.S. public universities is not fortuitous. While only seven institutions (47 percent) in the sample had a strategic plan during the timeframe of the study that specifically addressed university engagement in international development, all SIOs involved in the study acknowledge aspirations of their university or system to translate international development into broader international education activities. Thus, they develop projects and activities that contribute to their mission and complement other existing internationalization efforts. Both Knight (1994) and Hudzik (2011 2015) see intentionality essential to internationalization. Complementarity of international development activities with study abroad, internationalization of curriculum, transnational partnership, cross-border higher education provision, and international research allows international development efforts to reinforce comprehensive internationalization of U.S. public universities.

\section{International Development Contribution to Educational Mission}

All the U.S. public universities included in the study identified that involvement with developing countries contributes to their educational mission. Interviewed SIOs elaborated that their institutions of higher education first of all strive to engage students in their international development efforts to expose them to issues faced by developing countries. These activities allow public universities to create new learning opportunities to meet the needs of their student body.

Student participation in international development takes a variety of forms, including study abroad, service learning, internships, teaching, and research experiences. Universities build these activities into the architecture of their international development efforts to provide students with the possibility of gaining practical experience, enhancing their soft-skills and intercultural competencies, and allowing them to build global networks.

Similarly, universities see student engagement in international development increasing possible career paths for students. Meanwhile, graduate students benefit from international development activities, as they engage in research and teaching abroad, which contributes towards their degree. During the interview informants from SWS stated: "[w]e got a student who just came back from Cyprus, where he is looking at science education for reunification in Cyprus. We get students who are very involved, which is something that we want to do, and we want to provide opportunities or at least directions for students. We do not want them to read all the theory and then go away. We want them to have impact, so it is very much a part of how we ran our program."

However, one of the institutions included in the sample identified that graduate student engagement is a challenge in their institutional context. Key informants from MSS described their expectations for graduate education as focused on skills and on-campus work rather than engagement in the field. They highlighted that graduate students at their institution are expected to work in labs and acquire lab-based research skills, rather than conduct studies outside of campus. This represents a unique, yet interesting case, where graduate student engagement in international development efforts may come in conflict with the institutional approach to training their students. One of the key informants from the respective institution stated, "even if they [graduate students] are doing research in their home countries, people don't seem to think they are getting needed expertise."

International development activities also may provide universities with funding for training international students. There is a variety of experiences in providing education to international students both in their country of origin, as well as in the U.S. For example, through the U.S. Indonesia Teacher Education Consortium (USINTEC), universities in the U.S. and Indonesia developed dual master's degree and short-term graduate programs to improve Indonesian education and teacher quality (USINTEC 2016).

Understanding limited opportunities for students to study abroad, universities also seek to internationalize their curriculum and to further internationalization opportunities at home for students to learn about the challenges of developing countries, such as incorporation of global learning competencies in courses. International students on U.S. 
campuses also contribute to campus internationalization by creating new engagement opportunities for domestic students. Americans learn about global issues, different cultures and perspectives. Students develop international and intercultural competences by interacting with their foreign peers in the classroom and through various extracurricular activities. Practices discussed by the study participants complement existing literature on internationalization at home (Beelen and Leask 2011; Knight 2008).

Faculty engage in international development activities through their role as educators and researchers. International development activities create opportunities for faculty to gain more fieldwork, teaching, and learning experiences. Faculty members of the institutions included in the sample provide teaching and training for students in the U.S and from developing countries, and participate in curriculum development and capacity building initiatives. SIOs from SWS institution stated during the interview, "there is a [sic] lot of people who are engaged because they are interested in helping to develop education or provide teaching and training in these challenging areas." These experiences enhance the expertise of faculty members and allow them to further internationalize their curriculum. While this process is complicated, as discussed by de Wit and Leask (2015), international officers find it highly beneficial to improving the quality of higher education and student experience.

\section{International Development Contribution to Research Mission}

The fifteen universities involved in the study identified that engagement in international development activities significantly contributes to advancing their research mission. Their involvement with developing countries results in opportunities to obtain funding for creating new research partnerships and projects, disseminating new and existing knowledge, and applying it on the ground. Engagement in international development activities provides opportunities for studying factors that influence development itself, such as environmental, human, and cultural factors. Similarly, Keenan et al. (2012) discussed international cooperation in science, as the needed response to "grand challenges."

Research projects appear to be most attractive to institutions in the sample since they naturally fit into institutional missions to develop, advance, and disseminate knowledge. Furthermore, they align with faculty interests and have potential to contribute to their promotion and tenure. Faculty in area studies benefit from international development initiatives, which allow them to engage in communities of their research focus. Research projects can be of different scales. Examples provided by SIOs included individual faculty research, projects engaging several faculty members, and larger research initiatives that engage multiple departments and institutions. For example, the USAID 24 Feed the Future Innovation Labs engage 70 U.S. higher education institutions in agricultural research activities, alongside with universities in developing countries (Feed the Future 2018).

Universities conduct research projects in a variety of fields, which closely align with their faculty interests. A representative of SELG1 stated during the interview: "mainly what drives our decision to put together a proposal and take on projects depends on the faculty interests and the capability of the faculty... if we do not have faculty who are interested in the project, we [are] better not to go after it. We are not going to be a consulting firm. It goes back to having faculty who are interested to pursue the program, develop a proposal, and to implement it if it is awarded." This approach aligns with the existing scholarship, which sees research as a bottom-up activity dependent not so much on institutional strategies, but rather on behavior of faculty members (Woldegiyorgis, Proctor, and de Wit 2018).

Participants of the study reported engagement in twenty-four different sectors of international development. However, SIOs involved in the study acknowledge that they might not be aware of all the sectors involving their faculty members. Figure 2 demonstrates sectors of universities' international development activities, as identified by key informants during the interviews. 
Figure 2: Sectors of international development engagement
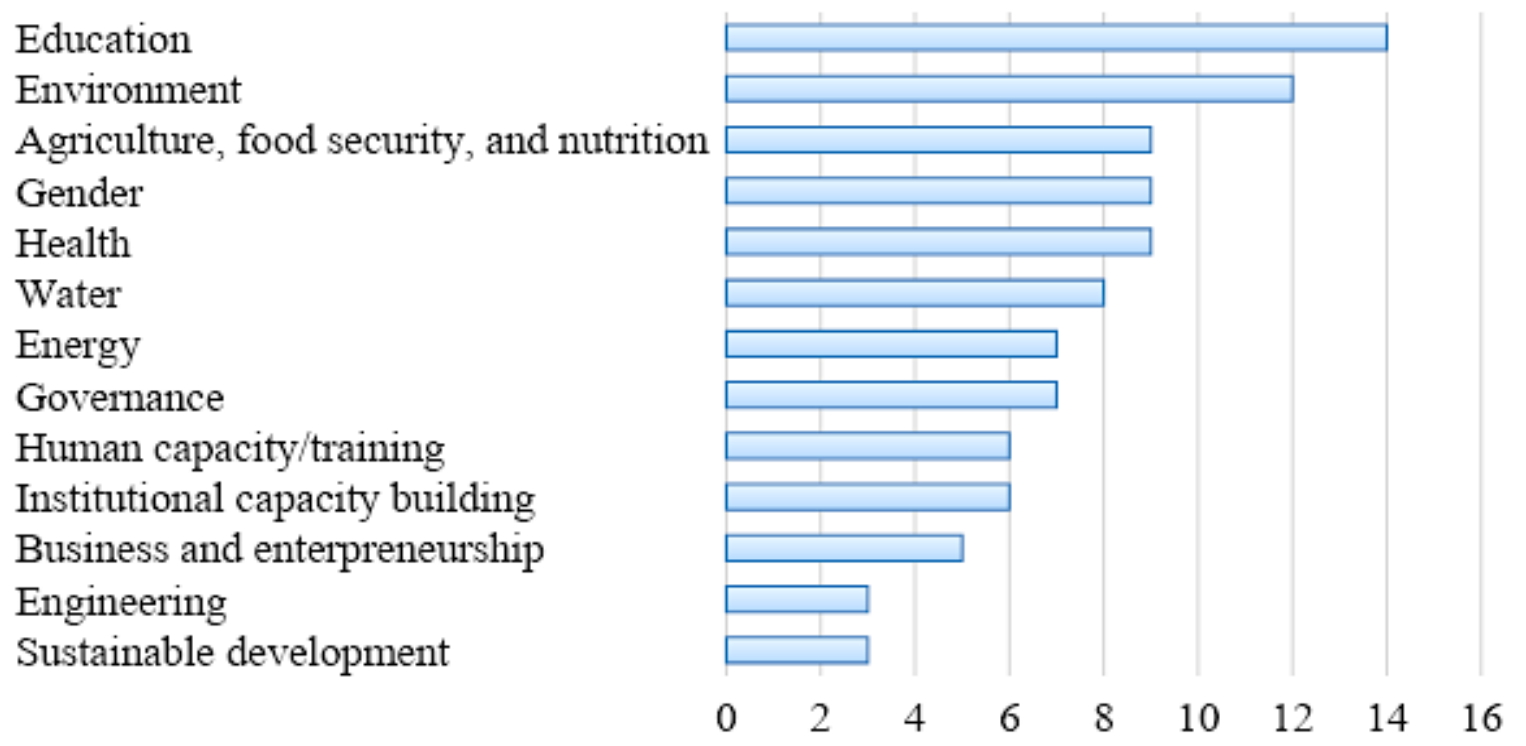

$\square$ Number of Universities Engaged in a Sector

As illustrated by Figure 2, fourteen universities are involved in educational activities in developing countries. Environment is the second most often named sector with twelve institutions engaged. Nine universities pointed out their participation in international development activities related to health, gender, agriculture, food security, and nutrition issues. Eight universities work on issues of water supply and quality in developing countries. Governance and energy involve seven universities from the sample. Six institutions indicated their involvement in institutional capacity building efforts. Similarly, six universities identified their work on human capacity development separately from education. Five institutions of higher education engage in business and entrepreneurship. They are followed by three universities, which highlighted their participation in sustainable development and engineering activities.

Additionally, SIOs see research in developing countries as an opportunity to enhance cooperation across various departments and units within a university. Challenges faced by developing country economies are often of an interdisciplinary nature. Consequently, faculty engagement in international development activities creates opportunities for intensifying interdisciplinary approaches in research and increasing cooperation between various departments on U.S. campuses.

In the study, participants presented two cases of institutionalizing interdisciplinary approach through establishing interdisciplinary health institutes on their campuses. One example is a system-wide problem-oriented global health institute. This institute focuses on issues of human rights, health access and inequalities, water and food safety, and population movements, looking at the relationship between migration, health, and diseases. The SIO from SELG1 discussed a second example during the interview:

We will cross college lines pretty easily to tackle a problem and in fact in our drive we have a lot of what we call cluster hires, which are tackling complex problems, like food systems and some public health issues. The cluster hires are grouped around a problem that requires a system approach to solving and requires more than one college... There is a real push to create institutes that are interdisciplinary and draw on all of that diversity and strengths. One of the examples would be the emerging pathogens institute, which is largely focused on pathogens of health-related issues but really works with people across the university in all sorts of ways.

However, study informants acknowledge several challenges in research and international development. First, they find it to be increasingly difficult to secure sufficient funding. International officers discussed increasing requirements 
for cost-share and shrinking overheads, which often do not make it possible for a university to put together a competitive proposal. A second challenge seen by international officers is shrinking opportunities for faculty to advance their career through engagement in international development activities. Heyneman (2016) elaborated on decreasing research and data collection in educational programming in developing countries, which limits engagement of faculty and scholars in international development initiatives. Several institutions in the study sample stated that they openly discourage tenure-track seeking faculty from participation in international development, since universities do not see these projects providing opportunities to publish in a timely manner.

\section{International Development Contribution to the Service Mission}

International development activities contribute to the service mission of public universities since development projects provide universities with opportunities to engage with communities worldwide. Increasing the understanding that many problems may be only "a plane ride away" puts universities in a position to engage in front-line responses to global problems through international development efforts.

Universities' determination to contribute to solving global challenges makes their involvement in international development a natural extension of their service mission. In such manner, ten institutions in the sample (67 percent) identified making a meaningful impact in developing countries as a major institutional and faculty motivator for international development work. Likewise, U.S. university engagement in international development aligns with missions of serving local communities in their respective states through universities engagement with international issues of particular interest to their local communities. As stated by SIO from NWS2 institution, "by engaging in the front-line responses to global epidemics like Ebola we contribute to solving the problems where they occur."

Analysis of the data across the institutional types allowed for the finding of important distinctions between state and land-grant universities represented in the study. While, all universities draw on their specific context to identify rationale for their international development activities, the original extension mission of land-grant universities plays an important role in their engagement in developing countries. The idea of a "global land-grant" university bridges the extension mission of these institutions with their activities in developing nations. Meanwhile, state universities build on their service mission to engage beyond their campuses, which is elaborated in this article through the discussion of the "Wisconsin idea."

Land-grant universities founded under the provisions of the Morrill Act of 1862 have a particularly long and extensive history of involvement in international development activities. Since the 1950s, they engaged in U.S. foreign development assistance (U.S. Congress 1991). The original extension mission of land-grant universities, such as teaching of practical agriculture, science, military science, and engineering, empowered their engagement with local communities in the U.S. Meanwhile, globalization posed a question of their role in meeting the needs of global society (Simon 2009). Thus, land-grant universities broaden their extension mission across borders to developing nations (Collins 2012).

The idea of global land-grant mission and transferability of the extension efforts of these institutions of higher education to developing nations has been discussed by all land-grant universities included in the sample. The study participant from NELG2 institution stated, "land-grant universities are not just about the development of the country. In this world... it is important to engage with communities everywhere. We view the land and sea-grant mission as a local mission that is connected globally."

The 20th president of Michigan State University, Lou Anna Kimsey Simon (2009) formulated the "World Grant" ideal. It calls upon land-grant universities to extend their mission beyond national borders and consider new ways for research-intensive universities to contribute to making a difference and addressing the vast societal challenges of the century. Extensive engagement of land-grant universities in poverty reduction and hunger prevention programs resonates with the idea of a global land-grant institution.

Strategies of land-grant universities included in the study also refer to the global land-grant idea. The strategy of SELG2 states, "[t]oday's land-grant university must address economic, societal, and technological needs of this 
generation. Our graduates must have the capacity to solve complex problems of a regional, national, and global scale that have yet to be envisioned. Now and in the future, we will use research and service to address global issues such as health, sustainability, resilience and security, and advance knowledge through technical assistance. Global recognition is a testimonial to comprehensive excellence."

Similar to the global land-grant idea, state universities aligned their international engagement with their service or outreach mission. Its globalization can be best explained through the framework of the "Wisconsin idea." It originated over a hundred years ago to link the University of Wisconsin with the community it serves. According to Witte (2000) it has three components. First, the university should provide advanced education to as many citizens as possible. Second, it should create, invent, and implement new discoveries and ideas to benefit the state. Finally, the expertise of the university should be used to benefit citizens and the institution. Thus, the idea broadens the borders of the university beyond the classroom, which in the globalization context can be seen as an argument for applying universities' expertise worldwide. In fact, the SIO of NESS elaborated during the interview that regional focus of their international development activities has been instructed by diaspora communities located in their state. They see engagement in their diaspora countries of origin, as a way to serve the state population beyond its borders.

\section{Conclusion}

This article brings attention to the role of international development in comprehensive internationalization of U.S. public universities to bridge the gap in current knowledge. First, the authors examined contributions made by international development activities to advancing core teaching, discovery, and service missions of higher education institutions. Second, the article elaborates on intentional approach employed by U.S. public universities. Third, the authors discuss synergy between university international development activities, as well as other international programming efforts. International activities of U.S. public higher education institutions take many forms, but uneven attention is given to them by scholars. While Hudzik's (2011) framework of comprehensive internationalization has potential to highlight the role of understudied international activities, most literature remains focused on student mobility and study abroad (Woldegiyorgis, Proctor, and de Wit 2018). Meanwhile, U.S. public universities have much experience engaging in international development activities.

The findings of the study demonstrate the contribution of international development activities to comprehensive internationalization efforts of public universities through advancement of education, research, and service missions. Findings align with research by Altbach and Knight (2007). The article demonstrates complementarity of international activities performed by higher education institutions, which allows for integration of study abroad, international research, internationalization of curricular, and international student and faculty recruitment into developmental efforts. However, institutional context may come in conflict with SIOs efforts to comprehensively internationalize. Requirements for student graduation and faculty promotion and tenure do not always align with internationalization goals of U.S. universities. As pointed out by Proctor and Rumbley (2018), internationalization efforts risk becoming too international and neglect local needs.

New models of participation need to be developed for non-mobile students in the U.S. and abroad. Internationalization at home through international students and faculty recruitment appears to be a well-spread measure. However, it inevitably faces criticism due to often association with brain drain and global competition (Hudzik 2015). Thus, efforts to bring more voices from developing countries into discussion of internationalization activities and their impact on various communities should continue (Kaul 2013). Internationalization of curriculum, development of joint degree programs, and long-term sustainable partnerships through international development activities may have much potential to reinforce reciprocity.

Importantly, findings of this study show that faculty engagement in internationalization is crucial for U.S. public universities. Higher education institutions see their faculty expertise as the major competitive advantage in 
international development activities. However, is there enough space for faculty to engage? Most institutions in this study acknowledge lack of alignment between internationalization goals of their institutions and faculty tenure and promotion policies, as also raised by American Council on Education (2017). What is more, similar to findings of Woldegiyorgis, Proctor, and de Wit (2018) on international research being a bottom-up process, many international development activities are initiated by faculty members. Long term effects of increasing intentions of SIOs to align all international efforts with a university strategy are not yet clear. This challenge represents an interesting direction for future research.

Little research is available on benefits to comprehensive internationalization from university engagement in international development. Uncertain funding for higher education institutions activities in international development (Heyneman 2016) represents a challenge that may significantly affect university efforts in developing nations. Accordingly, future studies of U.S. higher education institutions engagement in international development have opportunities to increase understanding of benefits brought by university efforts. Research on the impact of these engagements with local communities in the U.S. and abroad, as well as global commitments to addressing the world's greatest challenges, will also contribute to current scholarship.

\section{References}

Adesogan, Adegbola T. 2016. "Opportunities for International Research and Development Through the Feed the Future Innovation Lab for Livestock Systems.” Journal of Animal Science 94(5): 402-402

Altbach, Philip G., \& Knight, Jane. 2007. "The Internationalization of Higher Education: Motivations and Realities." Journal of Studies in International Education 11(3-4): 290-305.

Alvarez, Robert R., Jr. 1995. "The Mexican-U.S. Border: The Making of an Anthropology of Borderlands." Annual Review of Anthropology (24): 447-470.

American Council on Education. 2017. Mapping Internationalization on U.S. Campuses: 2017 Edition. https://www.acenet.edu/news-room/Documents/Mapping-Internationalization-2017.pdf

Asefa, Sisay, ed. 2010. Globalization and International Development: Critical Issues of the 21st Century. Kalamazoo, Mich.: W.E. Upjohn Institute for Employment Research.

Association of Public and Land-grant Universities.

2015. What is Missing in the United States' Long-Term Plan to End Dependence on Foreign Aid?. http://www.aplu.org/projects-and-initiatives/international-programs/knowledge-center-for-advancingdevelopment-through-higher-education/knowledge-center-library/the-case-for-us-development-assistance-tohigher-education-capacity-strengthening/file

2018. 2018 Annual Report. https://www.aplu.org/library/2018-aplu-annual-report/file

2019. Cooperative Extension Regions. https:/www.aplu.org/members/commissions/food-environment-andrenewable-resources/board-on-agriculture-assembly/cooperative-extension-section/ecop-members/regions.html

Baker, Andy. 2013. Shaping the Developing World: The West, The South, and The Natural World. Thousand Oaks, CA: Sage Publications.

Beelen, Jos, \& Leask, Betty. 2011. "Internationalisation at Home on the Move," in The Handbook: Internationalisation of Education, edited by E. Beerkens, M. Magnan, M. Söderqvist, \& H. G. Van Liempd. Berlin, Germany: Raabe Academic Publishers.

Collins, Christopher S. 2012. "Land-Grant Extension as a Global Endeavor: Connecting Knowledge and International Development." The Review of Higher Education 36(1): 91-124.

De Wit, Hans, \& Leask, Betty. 2015. "Internationalization, the Curriculum, and the Disciplines." International Higher Education 83(December): 10-12. 
Deardorff, Darla K., de Wit, Hans, Heyl, John. D., \& Adams, Tony. 2012. SAGE Handbook of International Higher Education [Electronic Resource]. Thousand Oaks, CA: London: SAGE.

Edwards, Jane. 2007. "Challenges and Opportunities for Internationalization of Higher Education in the Coming Decade: Planed and Opportunistic Initiatives in American Institutions." Journal of Studies in International Education 11(3-4): 373-381.

Feed the Future. 2018. A Decade of Progress. Feed the Future Results. Results Through 2018. https://www.feedthefuture.gov/progress2015/assets/2015_FTF_Progress_Report.pdf

Glaser, Barney G., \& Strauss, Anselm L. 1967. The Discovery of Grounded Theory: Strategies for Qualitative Research. Mill Valley, CA: Sociology Press.

Glesne, Corrine, \& Peshkin, Alan. 1992. Becoming Qualitative Researchers: An Introduction. White Plains, NY: Longman.

Grant Lewis, Suzanne, Friedman, Jonathan, \& Schoneboom, John. 2010. Accomplishments of the Partnership for Higher Education in Africa, 2000-2010. Report on a Decade of Collaborative Foundation Investment. https://www.fordfoundation.org/media/1760/2010-accomplishments-of-the-partnership-for-higher-education-inafrica.pdf

Gubrium, Jaber F., James A. Holstein, Amir B. Marvasti, \& Karyn D. McKinney. 2012. The SAGE Handbook of Interview Research: The Complexity of the Craft. 2nd ed. Thousand Oaks, CA: SAGE Publications, Inc.

Haslam, Paul A., Schafer, Jessica, \& Beaudet, Pierre. 2012. Introduction to International Development: Approaches, Actors, and Issues. (2nd ed.). Don Mills, Ontario: Oxford University Press.

Heyneman, Stephen P., \& Lee, Bommi. 2016. "International Organizations and the Future of Education Assistance." International Journal of Educational Development 48(May 2016): 9-22.

Hudzik, John K. 2011. Comprehensive Internationalization. From Concept to Action. http://www.nafsa.org/_/File/_downloads/cizn_concept_action.pdf

Hudzik, John K. 2015. Comprehensive Internationalization: Institutional Pathways to Success. (1st ed.). London; New York, NY: Routledge, 2015.

Kaul, Inge. 2013. The Rise of The Global South: Implications for the Provisioning of Global Public Goods. United Nations Development Programme. New York, USA. http://hdr.undp.org/sites/default/files/hdro_1308 kaul.pdf

Keenan, Michael, Cutler, Paul, Marks, John, Meylan, Richard, Smith, Carthage, \& Koivisto, Emilia. 2012. Orienting International Science Cooperation to Meet Global Grand Challenges. Science and Public Policy, 39(2), 166-177.

Knight, Jane. 1994. Internationalization: Elements and Checkpoints. Ottawa: Canadian Bureau for International Education.

Knight, Jane. 2008. Higher Education in Turmoil. The Changing World of Internationalization. Rotterdam: Sense Publishers.

Koehn, Peter H., Deardorff, Darla K., \& Bolognese, Kerry D. 2011. "Enhancing International Research and Development-Project Activity on University Campuses: Insights from U.S. Senior International Officers." Journal of Studies in International Education 15(4): 332-350.

Koehn, Peter H., Demment, Montag, \& Hervy, Anne-Clair. 2008. “Enhancing Higher education's Engagement in International Development: Africa-U.S. Partnerships." Journal of the World Universities Forum 1(6): 127-140.

Moss, Charles. 2019. Guest Editor - Impact Analysis of Interventions in Feed the Future Countries in Africa. Journal of Agribusiness in Developing and Emerging Economies 9(1): 2-3

Patton, M. Q. (2002). Qualitative Research \& Evaluation Methods. (3rd ed.). Sage Publications, Inc.

Potter, Robert B. 2014. "The Nature of Development Studies, ” in The Companion to Development Studies. (3rd ed.), edited by Desai, V. \& Potter, R.B. (pp. 16-20). New York, NY: Routledge.

Proctor, Douglas., \& Rumbley, Laura E. 2018. The Future Agenda for Internationalization in Higher Education: Next Generation Insights into Research, Policy, and Practice. New York, NY: Routledge. 
Rosenkranz, Rolf. "Global Development: What You Need to Know." Devex. https://www.devex.com/news/globaldevelopment-what-you-need-to-know-74999

Simon, Lou Anna. 2009. Embracing the World Grant Ideal: Affirming the Morrill Act for a Twenty First Century Global Society. http://worldgrantideal.msu.edu/_files/documents/monograph.pdf

Soubbotina, Tatyana P., \& Sheram, Katherine A.. 2000. Beyond Economic Growth: Meeting the Challenges of Global Development. Washington D.C.: The World http://www.worldbank.org/depweb/beyond/beyondco/beg_all.pdf

Taylor, Steven J., \& Bogdan, Robert. 1998. Introduction to Qualitative Research Methods: A Guidebook and Resource. (3rd ed.). Hoboken, NJ, US: John Wiley \& Sons Inc.

U.S. Congress, Office of Technology Assessment. 1991. New Opportunities for U.S Universities in Development Assistance, OTA-BP-F-71. Washington, DC: U.S. Government Printing Office.

USINTEC. 2016. Overview of USINTEC. https://usintec.org/overview/

Witte, John F. 2000. "Wisconsin Ideas: The Continuing Role of the University in the State and Beyond." New Directions For Higher Education 112(2000): 7-16.

Woldegiyorgis, Ayenachew A., Proctor, Douglas, \& de Wit, Hans. 2018. "Internationalization of Research: Key Considerations and Concerns.” Journal of Studies in International Education 22(2): 161-176. 